\title{
Global Comparisons for Developing a National Dementia Registry in Cuba
}

\author{
José Alberto González MD
}

\begin{abstract}
A review/analysis of current literature on exemplary multicenter registries of clinical dementias was conducted as a comparative basis for a proposed Cuban registry on cognitive impairment and dementia.

The study of mental health disorders has been predominantly based on clinical concepts and criteria, and only in recent years a public health approach has been applied. Traditional epidemiological studies do not reveal patterns of cognitive impairment and behavioral disorders (particularly dementias) in routine clinical practice in a defined geographic area, which would provide essential information for longterm planning and allocation of health and social resources. Thus, multicenter clinical registries have become an important source of clinical and epidemiological data on dementias in recent decades. This article addresses the Cuban proposal for an automated national dementia registry, comparing it to others internationally. The registry would be housed in the Neurology and Neurosurgery Institute, and
\end{abstract}

\section{INTRODUCTION}

Mild cognitive impairment and dementia are among the most important public health issues worldwide.[1] Given their association with aging and the trend towards longer life expectancies exhibited globally, these disorders have steadily increased in both crude incidence and prevalence over the past decade.

Dementia is a syndrome characterized by an acquired, progressive and persistent impairment of higher cognitive functions, personality, behavior, and content of consciousness (without changes in level of consciousness). It hinders people's satisfactory performance of their daily activities, work, and social life, and, ultimately, their independence. Loss of independence is one of the greatest frustrations, not just for these patients but also for their families, and it compromises affective relationships developed over a lifetime. Because of its impact on daily living and interpersonal relations, dementia requires not only a health care response but also a degree of societal commitment.

There is substantial regional variation in dementia prevalence, from $2.1 \%$ in West Sub-Saharan Africa to $8.5 \%$ in Latin America, with most regions falling between $5 \%$ and $7 \%$.[2] Dementia has multiple etiologies, including neurodegenerative diseases; the most prevalent type, Alzheimer disease (AD), accounts for the majority of dementia cases.[2] Its clinical picture (formally described in 1906 by Alois Alzheimer and later named by Emil Kraepelin) was surprisingly neglected for almost 80 years, but is now one of the neuropsychological disorders receiving most attention (in both basic and clinical research) and causing greatest concern on the part of families and health authorities.[3] It was declared a global health priority by WHO in 2012[1] and is considered by many to be the epidemic of our time.

Cuba's National Program for Older Adults, considered a priority and included in the Public Health Projections in Cuba for would include a duly protected surveillance network hosted on the Institute's website.

Such a multicenter dementia registry based on epidemiological surveillance methods and limited to a defined area would provide new, valid, representative and current data on dementia occurrence patterns by subtype, flow of case identification and referral from primary care, as well as the main clinical features of patients at the time of their first contact with health services. This information would support development of health planning policies for implementation of programs aimed at improved distribution of social and health resources in the affected population, monitoring of the disorder's natural evolution and identification of preventive measures. The scientific benefits would be equally important: production of new knowledge, generation of hypotheses for clinical research projects, standardization of diagnostic criteria, and promotion of multicenter research in both national and multinational centers.

KEYWORDS Dementia, Alzheimer disease, cognitive impairment, disease registries, public health, surveillance, Cuba
2015,[4] addresses dementia and disabilities. Dementia deaths (mainly $A D$ ) have increased in recent years. It was among the ten leading causes of death from 2007 to 2012,[5] becoming the 6th leading cause of death for all ages in 2011, with a rate of 31.4 per 100,000 population. The Alzheimer Section of the Cuban Neurosciences Society and the 10/66 Dementia Research Group have spearheaded recognition and study of dementia as a public health issue, as well as support for dementia patients and their families in Cuba.[6] The 10/66 Group has produced numerous important studies, reporting a prevalence of dementia in Cuba of $6.3 \%(\mathrm{Cl} 5.0 \%-7.7 \%)$ in population studies; [7] and in various local studies in clinical settings of $5.4 \%[8]$, $10.8 \%[9]$ and $27.3 \%$.[10]

Establishing research priorities is critical for funding allocation and coherent health research policies that, in a longterm and constantly evolving interactive process, eventually reduce the gap between what is studied and the scientific evidence needed for patient care and population health improvement.

An effective strategy for studying and controlling diseases is epidemiological surveillance-a dynamic, ongoing and systematic process to collect, analyze, interpret and disseminate descriptive data from different sources for monitoring public health problems. Its general objective is to provide ongoing technical guidance for decisionmakers on prevention and control activities, supplying updated data on disease incidence, determining factors and at-risk populations.[11] While epidemiological health surveillance originally applied only to the observation, tracking and control of infectious diseases, its use has since been expanded to other health problems with important social and public health implications.[12]

Epidemiological surveillance based on appropriately designed centralized registries provides reliable information for decision- 
making, planning and resource allocation for prevention, as well as for evaluation of the impact of disease-specific prevention/ intervention programs.[13] Furthermore, by combining information from different sources, it provides a timely epidemiological picture of the disease's incidence and prevalence. While registries have long been developed for cancer and heart disease, they are not common in the field of dementia, although some models do exist. Beginning in the 1980s, several initiatives have been undertaken in the USA (e.g., the Consortium to Establish a Registry for Alzheimer's Disease, CERAD),[13-16] Spain[17] and Argentina,[18] working with centralized data registries of patients with dementia in their respective countries, although registry methods and environments are not comparable.

This article aims to provide an overview of methodologies used in the dementia registries included in the specialized bibliography as a comparative context for a proposed Cuban registry of cognitive impairment and dementia (ReCeDemCu).[19]

\section{CENTRALIZED DEMENTIA REGISTRIES}

\section{AND EPIDEMIOLOGICAL SURVEIШANCE}

Various definitions have been put forward for a disease registry.[20] The US Agency for Healthcare Research and Quality (AHRQ) defines a registry as "an organized system that uses observational study methods to collect uniform data (clinical and other) to evaluate specified outcomes for a population defined by a particular disease, condition, or exposure and that serves predetermined scientific, clinical or policy purpose(s)."[21]

Although no standard definition for a dementia registry has been established, epidemiological information on dementia is derived mainly from three distinct types, depending on the origin of the subjects examined: 1) population registries, 2) hospital registries, and 3) "case study" registries. Population registries-the most common-are useful from an epidemiologic viewpoint, since they systematically include all cases of dementia occurring in a specific population and provide maximum reliability for epidemiological variables, such as incidence, prevalence, mortality and recurrence rates. Such registries are expensive, however, and their classification of dementia syndrome etiological subtypes is often incomplete; they also commonly overestimate measurement variables by over-rating symptoms.[16,18,22-28] Within this category of population registries there are also community studies, which are constrained by being limited to a specific geographical area and may show selection bias, but are useful for planning local allocation of social and health resources. An example is Spain's Girona Dementias Registry.[29]

Hospital registries have the advantage of recording more detailed data (clinical, neuroimaging, laboratory), which improves disease classification by etiological subtype, thus providing important information on clinical characteristics and enabling strategies for health resources allocation. However, these registries are most likely limited due to the bias of obtaining information dependent on the social and health characteristics of the catchment area, as well as the resources of their host facility. A further disadvantage of hospital registries is that most dementia patients are not hospitalized, so these registries are biased toward greater severity than is found in the underlying population. In addition, differences in clinical settings and methods make it difficult to compare information among hospital registries.[15,25,30]
Case study registries are useful for analyzing concrete clinical aspects or for recruiting patients for clinical trials. Most include outpatients;[13,22,29-31] some also include hospitalized ones. $[20,23,31]$ Few include a group of normal controls.[13,19,20] Most do not include pathology data.

Few registries currently rely on data collection solely in paper format.[18,19] In the New York State Dementias Registry, reports were initially on paper, but later included a computerized system designed to extract specific diagnostic codes from hospital discharge databases.[15] Most registries use a digital format. $[22,23,25-28]$

With regard to publication and access to information, some registries have reported only pilot studies; others have not made their data available.

Another essential factor is diagnostic criteria. Most registries use DSM IV or ICD 9 or 10. Some include specific criteria for various subtypes of dementia, in addition to research criteria for AD. $[18,30]$

There is no ideal dementia registry. But design features should be selected based on the study's objective. The registry should strike a balance between simplicity and completeness. Diagnostics employed should be clear and based on the most widely accepted and recommended criteria. There should be flexibility to add new variables in the future, and all patients included in the database should have undergone basic studies (clinical, neuropsychological and neuropsychiatric; as well as laboratory and neuroimaging exams). Patients in predemential or prodromal stages should be included to compile data on the early stages of the disorder. The registry should be easily accessed by other users so as to facilitate multicenter studies. Before starting to use the registry, the user should know, understand and commit to prospectively and consecutively including the variables analyzed for all patients registered, which requires discipline, rigor and perseverance.

Lack of consistency in terminology used by registries hinders access to information. Each registry is unique, with qualitative and quantitative differences in type, case definition, sample size, quality of design, purpose, procedures (to avoid case duplication and for tracking), costs, funding sources, dissemination and communication of results, and short- and long-term impact. This heterogeneity both reflects and contributes to a lack of concrete policies and strategies at the global, national and/or regional levels, and creates obstacles to data extrapolation to the local context. Consistency among registries needs to be improved for the purpose of attaining more homogeneity in reporting across registries.

Most registries reported were designed with clinical-epidemiological purposes to provide global data for health service programs and planning.[13,22,24-28,30] Other registries aim to recruit patients for clinical research on dementia.[23,24,31] Simultaneous establishment of registries with similar objectives and design could go a long way toward addressing the limitations identified.

No longitudinal or cohort studies on dementia have been conducted in Cuba because of the high cost and complexity of the long-term sustainability of such studies. Most epidemiological data on dementia in Cuba have been acquired using a classic epidemiological 
Table 1: Comparative data among cognitive impairment registries

\begin{tabular}{|c|c|c|c|c|c|c|c|c|c|c|c|}
\hline Registry & Country & Year & $\begin{array}{l}\text { Type of } \\
\text { registry }\end{array}$ & Main objective & $\begin{array}{l}\text { Pilot } \\
\text { study }\end{array}$ & $\begin{array}{c}\text { Data } \\
\text { collection }\end{array}$ & Patients & $\begin{array}{l}\text { Type of } \\
\text { patient }\end{array}$ & $\begin{array}{l}\text { Control } \\
\text { subjects }\end{array}$ & $\begin{array}{c}\text { Diagnostic } \\
\text { criteria }\end{array}$ & $\begin{array}{l}\text { Pathological } \\
\text { anatomy }\end{array}$ \\
\hline CERAD[13] & USA & 1976 & Population & $\begin{array}{l}\text { Clinical- } \\
\text { epidemiological }\end{array}$ & - & Paper & 1094 & Outpatient & Yes & $\begin{array}{l}\text { NINDS- } \\
\text { ADRDA }\end{array}$ & Yes \\
\hline CDCR[22] & $\begin{array}{l}\text { UK } \\
\text { (Camberwell) }\end{array}$ & 1983 & Population & $\begin{array}{l}\text { Clinical- } \\
\text { epidemiological }\end{array}$ & - & - & 559 & Outpatient & No & $\begin{array}{l}\text { NINDS- } \\
\text { ADRDA }\end{array}$ & Yes \\
\hline $\begin{array}{l}\text { ADRC } \\
\text { Registry[27] }\end{array}$ & $\begin{array}{l}\text { USA } \\
\text { (Pittsburgh) }\end{array}$ & 1986 & Population & Research & - & - & - & Outpatient & Yes & $\begin{array}{l}\text { NINDS- } \\
\text { ADRDA }\end{array}$ & Yes \\
\hline $\begin{array}{l}\text { NYS } \\
\text { Dementias } \\
\text { Registry[15] }\end{array}$ & $\begin{array}{l}\text { USA } \\
\text { (New York) }\end{array}$ & 1988 & Hospital & $\begin{array}{l}\text { Clinical- } \\
\text { epidemiological }\end{array}$ & - & Digital & 58,000 & $\begin{array}{l}\text { Hospital- } \\
\text { ized }\end{array}$ & No & CIE-9 & No \\
\hline ADPR[26] & $\begin{array}{l}\text { USA } \\
\text { (Washington) }\end{array}$ & 1988 & Population & $\begin{array}{l}\text { Clinical- } \\
\text { epidemiological }\end{array}$ & - & Digital & 1,000 & $\begin{array}{l}\text { Outpatient/ } \\
\text { hospitalized }\end{array}$ & Yes & $\begin{array}{l}\text { DSM III; } \\
\text { NINDS- } \\
\text { ADRDA }\end{array}$ & Yes \\
\hline $\begin{array}{l}\text { South } \\
\text { Carolina } \\
\text { Alzheimer's } \\
\text { Disease } \\
\text { Registry[16] }\end{array}$ & $\begin{array}{l}\text { USA } \\
\text { (South } \\
\text { Carolina) }\end{array}$ & 1988 & Population & $\begin{array}{l}\text { Clinical- } \\
\text { epidemiological }\end{array}$ & - & - & 150,853 & $\begin{array}{l}\text { Outpatient/ } \\
\text { hospitalized }\end{array}$ & No & CIE-9 & No \\
\hline ReDeGi[29] & $\begin{array}{l}\text { Spain } \\
\text { (Girona) }\end{array}$ & 2007 & Hospital & $\begin{array}{l}\text { Clinical- } \\
\text { epidemiological }\end{array}$ & Yes & Paper & 577 & $\begin{array}{l}\text { Specific } \\
\text { outpatient }\end{array}$ & No & $\begin{array}{l}\text { NINDS- } \\
\text { ADRDA }\end{array}$ & No \\
\hline SveDem[25] & Sweden & 2007 & Population & $\begin{array}{l}\text { Clinical- } \\
\text { epidemiological }\end{array}$ & - & Digital & 11,346 & Outpatient & No & - & No \\
\hline $\begin{array}{l}\text { West Virginia } \\
\text { Alzheimer's } \\
\text { Registry } \\
\text { (Pilot)[28] }\end{array}$ & $\begin{array}{l}\text { USA } \\
\text { (West } \\
\text { Virginia) }\end{array}$ & 2008 & Population & $\begin{array}{l}\text { Clinical- } \\
\text { epidemiological }\end{array}$ & Yes & Digital & 70 & Outpatient & No & $\begin{array}{l}\text { CIE-9; } \\
\text { CIE-10 }\end{array}$ & Yes \\
\hline $\begin{array}{l}\text { UK Dementia } \\
\text { Research } \\
\text { Registry[31] }\end{array}$ & $\begin{array}{l}\text { UK } \\
\text { (several } \\
\text { municipali- } \\
\text { ties including } \\
\text { London) }\end{array}$ & 2009 & Population & Research & Yes & Digital & - & $\begin{array}{l}\text { Outpatient/ } \\
\text { hospitalized }\end{array}$ & No & $\begin{array}{l}\text { DSM-IV; } \\
\text { CIE-10; } \\
\text { MCI }\end{array}$ & No \\
\hline $\operatorname{ReDeCAr[18]~}$ & Argentina & 2009 & Population & $\begin{array}{l}\text { Clinical- } \\
\text { epidemiological }\end{array}$ & Yes & Digital & 292 & Outpatient & No & $\begin{array}{l}\text { DSM-IV; } \\
\text { CIE-10; } \\
\text { NINDS- } \\
\text { ADRDA; } \\
\text { MCI; MBI; } \\
\text { specific* }\end{array}$ & Yes \\
\hline $\begin{array}{l}\text { Scottish } \\
\text { Dementia } \\
\text { Research } \\
\text { Interest } \\
\text { Register[24] }\end{array}$ & $\begin{array}{l}\text { UK } \\
\text { (Scotland) }\end{array}$ & 2010 & Population & Research & - & Digital & - & Outpatient & No & - & No \\
\hline $\begin{array}{l}\text { ReCeDemCu } \\
\text { (pilot)[19] }\end{array}$ & Cuba & $\begin{array}{l}2015 \\
\text { (proposed) }\end{array}$ & Population & $\begin{array}{l}\text { Clinical- } \\
\text { epidemiological }\end{array}$ & Yes & Digital & - & $\begin{array}{l}\text { Outpatient/ } \\
\text { hospitalized }\end{array}$ & Yes & $\begin{array}{l}\text { DSM-IV; } \\
\text { CIE-10; } \\
\text { NINDS- } \\
\text { ADRDA; } \\
\text { MCI; MBI; } \\
\text { specific* }\end{array}$ & Yes \\
\hline
\end{tabular}

ADPR: Alzheimer's Disease Patient Registry $\quad$ ADRC: Alzheimer's Disease Research Center, University of Pittsburgh $\quad$ CDCR: Camberwell Dementia Case Register CERAD: Consortium to Establish a Registry for Alzheimer's Disease MBI: mild behavioral impairment MCl: mild cognitive impairment

NINDS-ADRDA: National Institute of Neurological and Communicative Disorders and Stroke, and Alzheimer's Disease and Related Disorders Association

NYS: New York State ReDeCAr: Centralized Registry of Cases with Cognitive Impairment in Argentina ReDeGi: Girona Dementias Registry

ReCeDemCu: Cuban National Dementias Registry SveDem: Swedish Dementias Registry

- No published data available

*criteria for clinical subtypes

- vascular dementia: NINDS-AIREN criteria

- degenerative dementia with vascular component

- frontotemporal dementia: Lund-Manchester criteria

- Lewy body dementia: criteria from Consortium on DLB International Workshop

- dementia from progressive supranuclear palsy: NINCDS-SPSP criteria

- corticobasal syndrome: Litvan criteria

- dementia from multiple system atrophy: AAS-AAN criteria

- semantic dementia: Neary criteria

- primary progressive aphasia: Mesulam criteria 


\section{Perspective}

research model: cross-sectional or prevalence studies, with significant constraints that extend beyond the objectives of this article. Although they provide limited information on the long-term evolution of cases and their impact on the health system, such crosssectional or prevalence studies cannot be used for determining the real behavior of dementia, its detection, referral and diagnostics in regular clinical practice at the primary, secondary and specialized health care services levels, which is fundamental information for appropriate allotment of social-health resources in the country and rational medium- and long-term planning.

Application of the epidemiological method to the medical management of dementia and the identification of preventive strategies transcends the individual context to a greater population/environment/public-health context. A preliminary proposal was presented for a national centralized, automated registry on cognitive deterioration and dementia in Cuba[19] during the 50th Annual Scientific Conference of the Neurology and Neurosurgery Institute (INN).

The proposal outlines a plan to implement an automated National Dementias Registry (ReCeDemCu) as a source of clinicalepidemiological data based on the epidemiological surveillance model. A four-module data collection protocol or log for the model has been developed, based on the minimal variables necessary to implement the Registry: a) identification of the health center; b) demographic data and identification of the patient; c) diagnostic data; and d) relevant clinical variables. INN would be the central reference unit and a surveillance network would be set up and uploaded on a secure INN website. The registry's automated online format would enable 24-hour access for users and researchers throughout the year.

The Registry would enable description of incidence patterns by disease subtype, identify flows of case referrals from primary care, provide information on the workload of health services in different centers, identify patients' main clinical features, and generate hypotheses for new clinical research projects. Equally important would be the scientific advantage of generating new knowledge, unifying diagnostic criteria, and benefiting research and multicenter studies.

Initially, a pilot study has been proposed, scheduled to begin in 2015 (the design has been in place since 2013 but data collection has not yet begun), to test the operational structure of sentinel centers (hospitals, specialized centers and several primary health care facilities) where registries will be compiled and later extended to the rest of Cuba.[19] Table 1 compares some characteristics of the Cuban proposal with selected international registries in which the author found relevant data.

\section{FINAL CONSIDERATIONS}

Cognitive and behavioral disorders constitute a priority health problem, owing to their clinical and social impact, the progressive impairment they produce, and the care needs they create. This health issue needs to be addressed from a multidisciplinary perspective. A family member suffering from dementia has a great impact on his/her family and on society at large. Dementia produces so-called "hidden patients," namely, the family and, in particular, the primary caregiver. The condition affects the caregiver's quality of life, makes the patient's family vulnerable, has financial repercussions and creates the need for special services to assist patients, their caregivers and families.

Registries of patients with dementia provide a fundamental tool for identifying disease patterns in different regions and their variations according to multiple variables (clinical, epidemiological, investigative and administrative), as well as current treatment norms. Despite the wide differences in methods and results that our review found globally, it is extremely important to implement a national dementia registry in Cuba as a source of clinical and epidemiological data and as an efficient strategy to address this chronic disorder and its high social and health costs.

A centralized registry would enable correlation of clinical, neuropsychological, imaging and pathology findings. Epidemiological surveillance, through use and analysis of data from such a registry, would help inform and guide decisionmaking and planning of public health strategies for prevention and improved treatment.

Description and comparison of other registries in this review provide context for Cuba's first cognitive impairment registry, whose preliminary version, $\mathrm{ReCeDemCu}$, considers the limitations of existing registries and sets goals for improving their design to optimize care of Cuban patients with dementia. - 1/

\section{REFERENCES}

1. World Health Organization [Internet]. Dementia: a Public Health Priority. Geneva: World Health Organization; 2012 [cited 2012 Apr 13]. 112 p. Available from: http://www.who.int/mental health/publications/dementia report 2012/en/

2. Prince M, Bryce R, Albanese E, Wimo A, Ribeiro W, Ferri CP. The global prevalence of dementia: A systematic review and metaanalysis. Alzheimers Dement. 2013 Jan;9(1):63-75.

3. Prince M. Epidemiology of dementia. Psychiatry 2007;6(12):488-90.

4. Ministry of Public Health (CU). Proyecciones de la Salud Pública en Cuba para el 2015 [Internet] Havana: Ministry of Public Health (CU); 2006 Feb [cited 2012 Apr 13]. 68 p. Available from: http://www.nationalplanningcycles.org/sites/ default/files/country_docs/Cuba/cuba_proye cciones_de_la_salud_publica_para_el_2006 -2015.pdf. Spanish.

5. National Health Statistics and Medical Records Division (CU) Anuario Estadístico de Salud 2011
[Internet]. Havana: Ministry of Public Health (CU); 2012 Apr [cited 2012 Apr 13]. 233 p. Available from: http://files.sld.cu/dne/files/2012/04/ anuario-2011-e.pdf. Spanish.

6. Grupo de Investigación en Demencias 10/66 "GID 10/66" [Internet]. Havana: Ministry of Public Health (CU); 1999 [updated 2009; cited 2012 Apr 13]. Available from: http://www.alzheimer.sld.cu/ grupo-de-investigacion-1066. Spanish.

7. Llibre JJ, Ferri CP, Acosta D, Guerra M, Huang $Y$, Jacob KS. Prevalence of dementia in Latin America, India, and China: a population-based cross-sectional survey. Lancet [Internet]. 2008 Aug 9 [cited 2012 Apr 13];372(9637):464-74. Available from: http://www.thelancet.com/search/results?se archTerm=Prevalence+of+dementia+in+Latin+Am erica $\% 2 \mathrm{C}+$ India $\% 2 \mathrm{C}+$ and + China $\% 3 \mathrm{~A}+\mathrm{a}+$ populat ion-based+cross-sectional+survey\&fieldName $=\mathrm{Ar}$ ticleTitle\&journalFromWhichSearchStarted=lancet

8. Martínez C, Pérez VT, Carballo M, Varona G. Estudio clínico epidemiológico del síndrome demencial. Rev Cubana Med Gen Integr [Internet]. 2005 May-Aug [cited 2013 Sep 11];21(3-4). Available from: http://scielo.sld .cu/scielo.php?script=sci_arttext\&pid=S0864 $-21252005000300013 \&$ Ing=es. Spanish.

9. Sotolongo O, Rodríguez L. Prevalencia del síndrome demencial y la enfermedad de Alzheimer en pacientes del policlínico "Pedro Fonseca". Rev Cubana Med Gen Integr. 2012;28(4):694702. Spanish.

10. Psichatria.com [Internet]. Madrid: Spanish Psychiatry Society; c2014. Medina Alvarez P. Prevalencia de la Enfermedad de Alzheimer en la población mayor de 65 años. Policlínico 28 de Enero. Municipio Playa; 2006 [cited 2012 Apr 13]. Available from: http://www.psiquiatria.com/ imprimir.ats?24727. Spanish

11. Fariñas AT, Sierra RM Metodología para el diseño de sistemas de vigilancia. Reporte Técnico de Vigilancia [Internet]. 2006 [cited 2012 Apr 13];11(6). Available from: http://www 
.sld.cu/galerias/pdf/sitios/vigilancia/farinas .pdf. Spanish.

12. Garre-Olmo J, Flaque M, Gich J, Pulido TO, Turbau J, Vallmajo N, et al. A clinical registry of dementia based on the principle of epidemiological surveillance. BMC Neurol. 2009 Jan 28;9:5.

13. Fillenbaum GG, Beekly D, Edland SD, Hughes JP, Heyman A, van Belle G. Consortium to Establish a Registry for Alzheimer's Disease (CERAD): development, data base structure, and selected findings. Top Health Inf Manage. 1997 Aug;18(1):47-58

14. Larson EB, Kukull WA, Teri L, McCormick W, Pfanschmidt M, van Belle G, et al. University of Washington Alzheimer's Disease Patient Registry (ADPR): 1987-1988. Aging (Milano). 1990 Dec;2(4):404-8.

15. New York State Dementias Registry [Internet]. New York: New York State Department of Health; c2013 [cited 2012 Apr 13]. Available from: http:// www. health.state.ny.us/diseases/conditions/ dementia/alzheimer/dementia_registry_fact sheet.htm

16. Office for the Study of Aging (US) [Internet]. South Carolina: USC Arnold School of Public Health (US); c1988. Alzheimer's Disease Registry South Carolina: University of South Carolina (US); 2012 [cited 2012 Apr 13]. Available from: http://www sph.sc.edu/osa/alzheimers registry.html

17. López-Pousa S, Garre-Olmo J, Monserrat-Vila S, Boada-Rovira M, Tárraga-Mestre L, AguilarBarberà $\mathrm{M}$, et al. Propuesta para un registro clínico de demencias. Rev Neurol. $2006 \mathrm{Jul}$ 1-15;43(1):32-8. Spanish.

18. Melcona CM, Bartoloni L, Katz M, Del Mónaco $\mathrm{R}$, Mangone CA, Melcon MO, et al. Propuesta de un Registro centralizado de casos con Deterioro Cognitivo en Argentina (ReDeCAr) basado en el Sistema Nacional de Vigilancia Epidemiológica. Neurol Arg. 2010 Jul-Sep;2(3):161-6. Spanish.
19. González JA. Propuesta de un Registro Nacional Automatizado de Demencias en Cuba. Rev Cubana Salud Pública [Internet]. 2013 Apr-Jun [cited 2013 Sep 11];39(2):354-72. Available from: http://scielo.sld.cu/scielo .php?script=sci_arttext\&pid=S0864 -346620 13000200015\&Ing=es. Spanish.

20. Goldberg J, Gelfand HM, Levy PS. Registry evaluation methods: a review and case study. Epidemiol Rev. 1980;2:210-20.

21. Gliklich RE, Dreyer NA, editors. Registries for Evaluating Patient Outcomes: A User's Guide. 2nd ed. (Prepared by Outcome DEcIDE Center [Outcome Sciences, Inc. d/b/a Outcome] under Contract No. HHSA29020050035I TO3.) AHRQ Publication No.10-EHC049. Rockville (US): Agency for Healthcare Research and Quality; 2010 Sep.

22. Cooper B, Holmes C. The Camberwell Dementia Case Register: a valuable research tool. IPA Bulletin. 1997;14:23-4.

23. Roos LL, Nicol JP. A research registry: uses, development, and accuracy. J Clin Epidemiol. 1999 Jan;52(1):39-47.

24. Scottish Dementia Research Interest Register [Internet]. Perth (GB): Scottish Dementia Research Interest Register (GB); c2010 [cited 2012 Apr 13]. Available from: http://www.sdcrn .org.uk

25. Swedish Dementia Registry, SveDem [Internet]. Stockholm: Swedish Association of Local Authorities and Regions; Swedish Brain Power Network; c2014 [cited 2012 Apr 13]. Available from: http://www.ucr.uu.se/svedem/index.php/ about-svedem

26. University of Washington Alzheimer's Disease Patient Registry (ADPR) [Internet]. Washington, DC: University of Washington; c2014 [cited 2012 Apr 13]. Available from: http://depts.washington .edu/gim/research/research_adpr.htm
27. University of Pittsburgh Alzheimer's Disease Research Center [Internet]. Pittsburgh: University of Pittsburgh; c2014 [cited 2012 Apr 13]. Available from: http://www.adrc.pitt.edu/clinical core.asp

28. West Virginia Alzheimer's Disease Registry [Internet]. West Virginia: West Virginia University; c2014 [cited 2012 Apr 13]. Available from: http:// www.wvadr.hsc.wvu.edu/

29. Calvó-Perxas L, Osuna MT, Gich J, EligioHernández $\mathrm{E}$, Linares $\mathrm{M}$, Viñas $\mathrm{M}$, et al. Características clínicas y demográficas de los casos de demencia diagnosticados en la Región Sanitaria de Girona durante el período 2007-2010: datos del Registro de Demencias de Girona (ReDeGi). Rev Neurol. 2012 Apr 1;54(7):399-406. Spanish.

30. Garre-Olmo J, López-Pousa S, Monserrat-Vila S, Pericot-Nierga I, Turon-Estrada A, Lax-Pericall C. [The feasibility of a registry of dementias: clinical features and diagnostic coverage]. Rev Neurol. 2007 Apr 1-15;44(7):385-91. Spanish.

31. Iliffe S, Curry L, Kharicha K, Rait G, Wilcock $\mathrm{J}$, Lowery D, et al. Developing a Dementia Research Registry: a descriptive case study from North Thames DeNDRoN and the EVIDEM programme. BMC Med Res Methodol. 2011 Jan $27 ; 11(1): 9$.

\section{THE AUTHOR}

José Alberto González Cáceres (drjosealber togc@gmail.com), family physician and neurologist. Adjunct researcher, Neurology and Neurosurgery Institute, Havana, Cuba.

Submitted: June 24, 2013

Approved for publication: November 10, 2014 Disclosures: None 